\title{
Trend analysis of annual and seasonal rainfall to climate variability in North-East region of India
}

\section{G. T. Patle* and A. Libang}

Department of Soil and Water Engineering, College of Agricultural Engineering and Post Harvest Technology (Central Agricultural University), Gangtok-737135, INDIA

*Corresponding author. E-mail: gtpatle77@gmail.com

Received: February 08,2014 ; Revised received: July 07, 2014 ; Accepted: October 13, 2014

Abstract Global warming, climate change and its consequences are major threat for the global agriculture. The agriculture in the North-East region of India is supposed to more in danger due to its topographic features. Agriculture in the state of Arunachal Pradesh is dependent on rainfall and variability in rainfall due to climate change is expected to threaten the food production in future. This study examines the impact of climate change on rainfall using the trend analysis technique for the four districts of Arunachal Pradesh. For this purpose temporal trends in annual and seasonal rainfall were detected using nonparametric Mann-Kendall test at $5 \%$ significance level. The daily time series rainfall data for the period 1971-2007 were analyzed statistically for each district separately. The results of Mann Kendall test showed decreasing trend in annual mean rainfall in east Siang, upper Siang and lowers Dibang valley and no trend in the west Siang district over the period of 1971-2007. In case of east Siang, upper Siang and lower Dibang valley districts, decreasing trend of rainfall was observed in the post monsoon season with slope magnitude of $3.01 \mathrm{~mm} / \mathrm{yr}, 3.32 \mathrm{~mm} / \mathrm{yr}$ and $3.95 \mathrm{~mm} / \mathrm{yr}$ respectively. Decreasing pattern of rainfall in post monsoon season may affect the vegetable and fruit production in the winter season.

Keywords: Climate change; Mann-Kendall; Rainfall; Seasonal; Trend analysis

\section{INTRODUCTION}

Climate is the driving force for the several human activities including agriculture. Global warming and its consequences have made the changes in the global and regional climate and can affect land ecosystems especially water cycle. Climate change and variability in the climatic parameters may adversely affect the agriculture and water resources of agrarian country like India (Sinha et al., 1998; Kumar et al., 2004; Mall et al., 2006;). Agricultural crop production system is greatly influenced by the climate and climatic parameters namely temperature and rainfall. Rainfall is useful in the planning and management of agriculture and irrigation projects and any change in this variable can influence the sustainable food production and water availability for the agriculture. Uncertainty of rainfall and uneven temporal and spatial distribution in one hand, creating flooding and of the other hand longer dry spells evoking drought conditions. Increase in precipitation trends can also result in an increase in the frequency of floods and could thereby affect water quality. On the other hand, a decrease in rainfall trend could imply an increase in instances of drought. Climate change studies are mainly focused on the probable changes in the climatic parameter such as rainfall or temperature and variability of these parameters is important. Several climate change models (physical models) are being used to study the long term changes in climate parameters on temporal and spatial scale (IPCC, 2001; INCCA, 2010; Krishna Kumar et al., 2011).

Temporal and spatial variability of climatic parameters can also be studied using statistical approach through the analysis of long term climatic data (Patle et al., 2013). Climatic variability of time series data can also be investigated using parametric and non-parametric statistical methods. The parametric method considers that data is normally distributed and is free from outliers but non-parametric methods are free from any such assumption (Hamed and Rao, 1998). The most widely used non-parametric method for analyzing the trend in the time series is the Mann-Kendall test (Mann, 1945; Kendall, 1955). Several researchers have widely used this method for different hydro-meteorological parameters (Aziz and Burn, 2006; Mondal et al., 2012).

Arunachal Pradesh is one of the hilly states of the northeast region of India. The region is characterized by difficult terrain, wide variations in slopes and altitudes, land tenure systems and indigenous cultivation practices and about $70 \%$ of the peoples in the state are dependents on the agriculture and forests for their livelihood. Shifting cultivation is a main feature in the 
Table 1. Statistics and Mann-Kendall analysis of annual mean rainfall.

\begin{tabular}{lcccccc}
\hline District & mean & SD & CV & Z & Q & Trend \\
\hline East siang & 3349.2 & 972.5 & 29.04 & -2.03 & -34.80 & FT \\
Upper siang & 3466.5 & 1038.9 & 29.97 & -2.11 & -38.98 & FT \\
West siang & 3174.3 & 836.7 & 26.36 & -1.87 & -25.70 & NT \\
Lower Dibang valley & 3541.4 & 1115.7 & 31.50 & -2.13 & -42.96 & FT \\
\hline
\end{tabular}

Where, NT represents no trend and FT shows falling trend

Table 2. Mann-Kendall analysis of seasonal rainfall.

\begin{tabular}{lccccccccc}
\hline \multirow{1}{*}{ District } & \multicolumn{3}{c}{ Pre-monsoon } & \multicolumn{3}{c}{ Monsoon } & \multicolumn{3}{c}{ Post-monsoon } \\
\cline { 2 - 10 } & Test Z & $\mathbf{Q}$ & Trend & Test Z & Q & Trend & Test Z & Q & Trend \\
\hline East siang & -1.69 & -7.55 & NT & -1.50 & -24.18 & NT & -2.13 & -3.01 & FT \\
Upper siang & -1.43 & -6.76 & NT & -1.58 & -25.81 & NT & -1.90 & -3.32 & FT \\
West siang & -1.77 & -7.17 & NT & -1.48 & -17.66 & NT & -0.94 & -1.78 & NT \\
Lower Dibang valley & -1.48 & -6.71 & NT & -1.58 & -28.46 & NT & -2.34 & -3.95 & FT \\
\hline
\end{tabular}

Where, NT represents no trend and FT shows falling trend

state. The variation in rainfall due to climate change may affect the agriculture and water resources in future. In view of above, this study was undertaken to detect the temporal trends in the annual and seasonal time series of rainfall which will be helpful for agricultural planning and in devising the location specific climate change mitigation and adaptation strategies.

\section{MATERIALS AND METHODS}

Study area comprises the four districts of Arunachal Pradesh namely east Siang, west Siang, upper Siang and lower Dibang valley. Arunachal Pradesh is located between $26.28^{\circ} \mathrm{N}$ and $29.30^{\circ} \mathrm{N}$ latitude and $91.20^{\circ} \mathrm{E}$ and $97.30^{\circ} \mathrm{E}$ longitude and having a total geographical area of $83,743 \mathrm{sq} . \mathrm{km}$. The climate varies from hot and humid in the Shivalik range with heavy rainfall. Arunachal Pradesh receives heavy rainfall of 2,000 to $4,100 \mathrm{~mm}$ during the months of May and September. The land use statistics in the state shows that $61.54 \%$ of the area is under forest and only $2.31 \%$ of the total geographical area under different crops. Agriculture is a mainstay and source of income for most of the peoples. The total area under agricultural operation in the state was 3, 43,719 ha in 2005-06 and net sown area was 203600 ha. The daily time series data of rainfall were obtained from NICRA project for the period of 1971-2007. The data were transformed to annual and seasonal time series of rainfall and were statistically analyzed. Three seasons were considered viz., pre monsoon, monsoon and post monsoon season. Variability in rainfall over the period of 37 years was assessed by non parametric Mann Kendall and Sen's slope estimator. The Mann-Kendall test, a non-parametric method was used for trend analysis of time series data (Mann, 1945; Kendall, 1975). Monotonic trend (increasing or decreasing) in the time series of annual and seasonal rainfall was tested based on the normalized $\mathrm{Z}$ statistics value. Negative value of the $\mathrm{Z}$ statistics represents the decreasing trend and positive value of $\mathrm{Z}$ statistics shows the increasing trend of rainfall. The trends were detected at 5\% level of significance and the probability density function (pdf) was computed. The trend is said to be significant if the computed pdf is greater than the level of significance. Non parametric Sen's slope estimator (Sen, 1968) was used to calculate the change per unit time. The slope of the trend gave the rate of increase or decrease in the annual and seasonal trend and the direction of change (Choudhury et al., 2012).

\section{RESULTS AND DISCUSSION}

Trends in annual mean rainfall: In case of annual mean rainfall, summary statistics revealed that coefficient of variation was $29.04 \%, 29.97 \%, 26.36 \%$ and $31.50 \%$ for east Siang, upper Siang, west Siang and lower Dibang valley respectively. From this it was observed that there was more variation in the annual rainfall within the districts. Negative value of $\mathrm{Z}$ statistics revealed decreasing trend in annual mean rainfall in all four districts. Results of the non-parametric Mann-Kendall test at the 5\% significance level shows the significant decreasing trend in east Siang, upper Siang and lower Dibang valley districts. West Siang showed the decreasing trend in the annual mean rainfall which was not statistically significant and considered as no trend. From the Sen's slope estimator revealed that the rate of decrease in the annual rainfall was more in the lower Dibang valley $(-42.96 \mathrm{~mm} / \mathrm{yr})$ followed by the upper Siang $(-38.98 \mathrm{~mm} / \mathrm{yr})$ and the east Siang $(34.80 \mathrm{~mm} / \mathrm{yr})$ over the period 1971-2007 (Table 1 and Fig.1). From this it may be concluded that annual mean rainfall has decreased from 1971 to 2007 for the three districts and is expected to follow the same trend in the future. As all three districts are of hilly terrain with few water storage facilities, water availability for agriculture is a major concern. Many studies have attempted to 

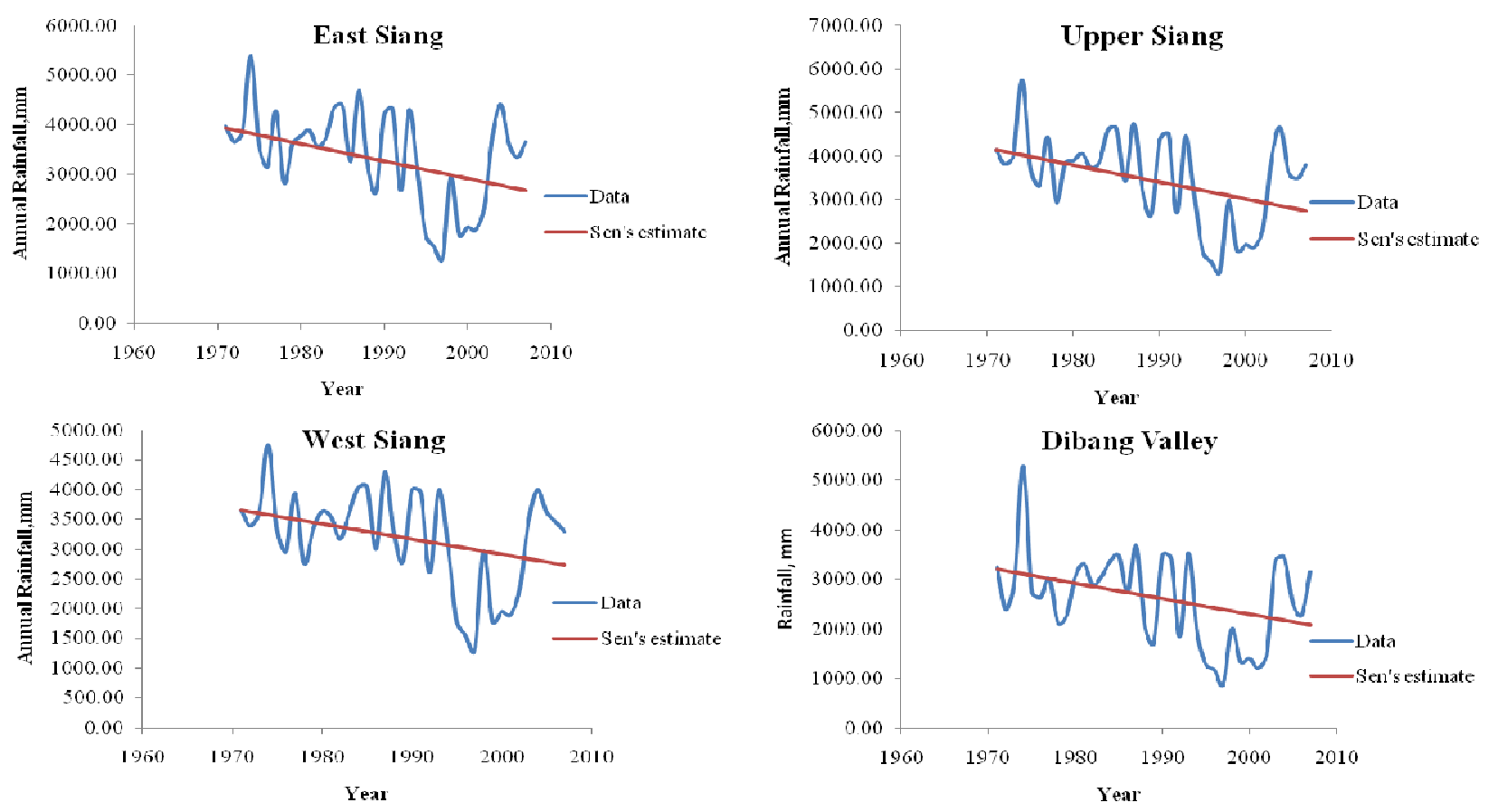

Fig. 1. Sen's linear estimates of annual mean of daily time series.

determine the trend in rainfall at different scales namely country, regional or district levels and the similar results have been reported by the several researchers for monthly, seasonal and annual series of rainfall. Yue and Hashino (2003) studied long term trends in annual precipitation of in Japan and found significant negative trends. Partal and Kahya (2006) also reported a negative trend in annual precipitation for the majority of stations in Turkey at the 5\% level of significance. Decreasing trend in the annual mean rainfall was also observed by Sarangi and Kumar (2009) for New Delhi and Soman et al. (1988) for stations in the hilly terrain of Kerala. Kumar and Jain (2010) also observed decreasing trend in annual rainfall for Srinagar, Kulgam, Handwara stations in Kashmir valley of India.

Trends in seasonal rainfall : Table 2 shows the trends in seasonal rainfall patterns for pre monsoon, monsoon and post monsoon seasons. Negative value of $\mathrm{Z}$ statistics revealed non-significant decreasing trend in the pre monsoon and monsoon season in all four districts namely east Siang, upper Siang, west Sing and lower Dibang valley over the period 1971 to 2007 . In case of post monsoon significant decreasing trend was observed for east Siang, upper Siang and lower Dibang valley with slope magnitude of $-3.01 \mathrm{~mm} / \mathrm{yr},-3.32$ $\mathrm{mm} / \mathrm{yr}$ and $-3.95 \mathrm{~mm} / \mathrm{yr}$ respectively. Krishnakumar et al. (2009) studied the temporal variability of seasonal and annual rainfall over Kerala for 1871-2005 and reported significant decrease in south-west monsoon rainfall and an increase in post-monsoon season whereas in our study significant decrease in post monsoon rainfall is observed. Similarly, decrease in the monsoon rainfall and non significant increase in post monsoon rainfall in Umiam of Meghalaya state was reported by Choudhury et al. (2012). Kothyari and Singh (1996) also found decreasing trend in monsoon rainfall in the Ganga basin. Rainfalls during the post monsoon season play a significant role in the crop intensification, particularly in rainfed agriculture of north east India (Choudhury et al., 2012) and may affect the vegetable and fruit production in the winter season.

\section{Conclusion}

Trend analysis of seasonal and annual mean rainfall (1971-2007) of east Siang, upper Siang, west Siang and the lower Dibang valley districts of Arunachal Pradesh was carried out using non parametric Mann Kendall and Sen's slope test. From the analysis it was concluded that annual mean rainfall had decreasing trend in east Siang, upper Siang and lowers Dibang valley districts. No trend was observed in the annual mean rainfall for west Siang district over the period 1971-2007. In case of east Siang, upper Siang and lower Dibang valley districts, decreasing trend of rainfall was observed in the post monsoon season with slope magnitude of $-3.01 \mathrm{~mm} / \mathrm{yr},-3.32 \mathrm{~mm} / \mathrm{yr}$ and -3.95 $\mathrm{mm} / \mathrm{yr}$ respectively. Decreasing pattern of rainfall in post monsoon season may affect the vegetable and fruit production in the winter season. Thus, temporal variability of seasonal and annual rainfall may affect the agricultural crop production and future water availability in the hilly state of Arunachal Pradesh.

\section{REFERENCES}

Aziz, O.I.A. and Burn, D.H. (2006). Trends and variability in the hydrological regime of the Mackenzie river basin. Journal of Hydrology, 319(1-4): 282-94.

Choudhury, B. U., Das, A., Ngachan S. V., Slong, A., 
Bordoloi, L. J. and Chowdhury, P. (2012). Trend analysis of long term weather variables in mid altitude Meghalaya, North-East India. Journal of Agricultural Physics, 12 (1): 12-22.

INCCA (2010). Indian network for climate change assessment, Climate Change and India: A 4x4 Assessment, Ministry of Environment and Forests, Government of India, 2010.

IPCC (2001). Climate change: the scientific basis. Intergovernmental panel on climate change. Cambridge (UK): Cambridge Univ. Press.

Hamed, K. H. and Rao, A. R. (1998). A modified Mann-Kendall trend test for auto-correlated data. Journal of Hydrology, 204:182-196.

Kendall, M.G. (1955). Rank Correlation Methods, Charles Griffin: London.

Kendall, M. G. (1975). Rank Correlation Methods, 4th edition. Charles Griffin, London, U. K.

Kothyari, U. C. and Singh, V. P. (1996). Rainfall and temperature trends in India. Hydrological Processes, 10: $357-372$.

Krishna Kumar, K., Patwardhan, S. K., Kulkarni, A., Kamala, K., KoteswaraRao, K. and Jones, R. (2011). Simulated projections for summer monsoon climate over India by a high-resolution regional climate model (PRECIS). Current Science, 101(3): 312-26.

Krishnakumar, K. N., Prasada Rao, G. S. L. H. V. and Gopakumar, C. S. (2009). Rainfall trends in twentieth century over Kerala, India. Atmospheric Environment, 43(11): 19401944.

Kumar, K. K., Kumar, K. R., Ashrit, R. G., Deshpande, N. R. and Hansen, J. W. (2004). Climate impacts on Indian agriculture. International Journal of Climatology, 24 (11): 1375-93.

Kumar, V. and Jain, S. K. (2010). Trends in seasonal and annual rainfall and rainy days in Kashmir Valley in the last century. Quaternary International, 212(1): 64-69.

Mall, R. K., Singh, R., Gupta, A., Srinivasan, G. and Rathore, L. S. (2006). Impact of climate change on Indian agriculture: A review. Climatic Change, 78 (2-4): 445-78.

Mann, H. B. (1945), Non-parametric test against trend. Econometrica, 13:245-259.

Mondal, A., Kundu, S. and Mukhopadhyay, A. (2012). Rainfall trend analysis by Mann-Kendall test: A case study of north-eastern part of Cuttack district, Orissa. International Journal of Geology, Earth and Environmental Sciences, 2(1):70-78.

Partal, T. and Kahya, E. (2006). Trend analysis in Turkish precipitation data. Hydrological processes, 20: 2011-2026.

Sen, P. K. (1968). Estimates of the regression coefficient based on Kendall's tau. Journal of the American Statistical Association, 39: 379-1389.

Sinha, S. K., Singh, G. B. and Rai, M. (1998). Decline in crop productivity in Haryana and Punjab: Myth or reality. Indian Council of Agricultural Research, New Delhi, India, 89.

Patle, G. T., Singh, D. K., Sarangi, Rai, A., Khanna, M. and Sahoo, R. N. (2013). Temporal variability of climatic parameters and potential evapotranspiration. Indian journal of Agricultural Sciences, 83 (4): 518-524.

Sarangi, A. And Kumar, A. (2009). Trend analysis of long term rainfall data for crop planning as an adaptation measure to climate change. 60th International Executive Council Meeting \& 5 th Asian Regional Conference, 611 December 2009, New Delhi, India: 1-6.

Soman, M. K., Krishna Kumar, K. and Singh, N. (1988). Decreasing trend in the rainfall of Kerala. Current Science, 57: 7-12.

Yue, S. and Hashino, M. (2003). Long term trends of annual and monthly precipitation in Japan. Journal of the American Water Resources Association, 39: 587-96. 